\title{
ORIGIN AND MONOPOLY RIGHTS OF ANCIENT FERRIES.
}

The law of ancient ferries is a fertile field for research into the early growth of our legal institutions. The numerous cases which assert that ancient ferries can be had either by a grant from the sovereign or prescription do not explain their origin. ${ }^{1}$ That every ferry is not an ancient ferry and that the law applicable to ancient ferries is quite different from that of ordinary ferries is evident from the cases. ${ }^{2}$ In order to understand how this privilege or franchise grew up, one must first understand the law of tolls of which the toll for ferriage, called passage, ${ }^{3}$ is a part. In the old abridgements there is no special treatment of the law applicable to ferries, but it is to be found either under the headings "Franchise", or "Tolls"."

In legal phraseology the word "toll" has been used, as is customary in the English language, to express two different legal rights. A toll most properly speaking is the payment for the right to buy and sell at a fair within the precincts of a manor. ${ }^{5}$ This toll was paid by the buyer of the goods at the fair to the owner of the market and it was an indictable offense for the lord to accept toll from the seller. ${ }^{6}$ Its origin, according to the ancient Mirror of Justice ${ }^{7}$ dates back to a statute passed in the reign of King Alfred. By this statute it was enacted that fairs and markets should be held in specified places and that the buyer should pay a toll to the bailiffs of the lords of the markets. This toll was evidence of a contract made in public since all private or

${ }^{1}$ However a good discussion can be found in Mr. Justice Story's dissent in the Charles River Bridge Case, infra, note 77.

${ }^{2}$ Letton .v. Godden, L. R. 2 Eq. I22 (Eng. 1866).

'Blount's Law Dict. (1679); Sheppard's Abridg. IIg (1675).

"I3 Viner's Abridg. 506, under "Franchises", and I7 Ibid. 289, under "Tolls"; 5 Comyn's Abridg. 290, under "Piscary"; Sheppard's Abridg., under "Tolls". 289.

'Terms de la Ley (1675); Sheppard's Abridg. 119; I7 Viner's Abridg.

' Coke's Second Inst. 22r. citing 2 \& $3 \mathrm{Ph}$. \& Mar., and 3I Eliz.

This treatise was written in 1675 and is generally attributed to Andrew Horne; see excellent translation of it in Selden Society list.

(718) 
secret contracts had been prohibited. The statute provided a certain list of tolls, but no toll was to exceed one penny for one kind of merchandise. Sir Edward Coke accepted this as the true explanation of the origin of tolls. This toll was not an incident to the fair ${ }^{8}$ and had to be held by prescription or exist in the same grant which created the fair $;^{\theta}$ a grant of a right to take toll subsequent to the grant of the fair was void as an oppression. ${ }^{10}$

There were divers other tolls and the peculiar feature about each one is that there was a service rendered for the sum exacted. They may be roughly grouped into those which pertained to towns and fairs; those which pertained to ports of entry; those which pertained to highways. Those which pertained to markets and towns were : stallage, a toll for setting up a stall in the market; picage, for the privilege of digging up ground in a market for a stall $;^{11}$ toll-turn, for beasts driven to the fair which were not sold ${ }^{12}$ (this could only be claimed by ancient custom or prescription and not by grant) $;^{\mathbf{1 3}}$ murage, for the keeping of the wall of the city as a defense and paid by all who enter. ${ }^{14}$ The tolls which were associated with ports of entry were: wharfage, for the privilege of landing goods upon, or loading them from a wharf $;^{15}$ tonnage, for weighing ${ }^{16}$ cranage, for the drawing of merchandise out of ships to the wharf ;17 anchorage, for the privilege of

'Anon, 7 Mod. I2 (Eng. I70I).

- Supra, note 6, at page 220 .

10 Bracton (Legibus Angliae, Lib. II, Chap. 24, s. 3), also speaks of Toll in the sense of a liberty to be free from toll. In Blount's Law Dictionary (1670) under "Toll" is the following: "Of this freedom from toll, the City of Coventry boasts of an ancient charter granted by Leofric (or Luriche) Merciorum Comes who at the importunity of Godiva, his virtuous Lady, granted this Freedom to that city; and in Richard the Second's time (according to Mr. Dugdale on his description of Warwickshire) the picture of him and his lady was set up in the South-Window of Trinity Church there, holding in his right hand a Charter, with these words written thereon:

'I Luriche for the love of thee

11 'Sheppard's Abridg. IIg.

Do grant Coventry Toll-free."

${ }^{21}$ Terms de la Ley (1615), I85. This toll was paid on the return from the fair. Blount's Law Dict.- "Toll."

${ }^{12}$ Coke's Second Inst. 221.

"Supra, note II.

${ }^{11} 3$ Bouvier Law Dict. 3450 (3d Rawle Revision, 1914).

"Jehu Webbs Case, 8 Coke Rep. 45b, 46b (I608).

Ir Ibid. 
casting an anchor from ship in a port. ${ }^{18}$ The last general class is the one which is especially applicable to the question at hand and embraces those tolls which were exacted for the privilege of travelling on highways. Pontage was a toll for the right to cross over a bridge $; ;^{19}$ pavage, for the right to travel on a highway and was used for the paving of a street or causeway $;{ }^{20}$ passage, for the transporting of man, beast or goods over water by boat. ${ }^{21}$

All these secondary tolls are divisible with respect to their origin into two classes: (I) Toll traverse; (2) Toll thorough.

A toll traverse was properly a payment of a certain sum for passing over the soil of another on a way not a high street. This was the definition given by $\mathrm{Mr}$. Justice Thorp as early as $1344{ }^{22}$ The toll lay in prescription; in fact Fitzherbert says that the tolltaker must justify it by usuage time out of mind for he already had his ordinary remedy by damage feasant. ${ }^{23}$ Anyone who had a right to charge a toll traverse could demand the toll from every one, even the King. There could be no grants of toll free from this species of toll, ${ }^{24}$ as there could be from the toll thorough.

A toll thorough is properly a toll taken of men for passing through a vill on the public highway. ${ }^{25}$ At a very early date it was the law that no one could have such a toll either by grant or prescription. ${ }^{28}$ The reason was that the highway was open to all and a grant by the King to one which enabled him to charge the people for being where they had a lawful right to be was void as an oppression. ${ }^{27}$ Neither could it be gained by prescription

${ }^{12}$ I Bouvier's Law Dict. I92 (3d Rawle Revision, 1914).

${ }^{19}$ Supra, note I6.

"Supra, note II. Coke, supra, note 16 , called it pannagium, but the editor states that this term is properly a liberty for hogs to feed on acorns, etc.

${ }^{21}$ Supra, note 16.

${ }^{2} 22$ Ass. 58. See also, Smith v. Shepherd, 7 Croke Eliz. 7Io (I600); Heshord v. Wills, I Sidf. Rep. 454 (167I).

2 Fitzherbert's Abridg. "Toll", pl. 3.

${ }^{24}$ Lord Berkley's Case, 46 Edw. III (1372), cited in Plowden's Comm. 236.

${ }^{25}$ Supra, note 22.

* Ibid.

${ }^{27}$ Fitzherbert's Natura Brevium, 227 (518, 8th ed.), citing 22 Ass. 58; I7 Viner's Abridg. 295. This appears to have been the early rule. Heddy v. Welhouse, Moore Rep. 474 (I598). 
because the right of the King's subjects to go on the King's highway antedated any supposed grant from time immemorial, and hence the presumption that the toll had a legal origin was impossible. ${ }^{28}$ But later the idea grew up that if consideration was shown for charging this toll, then a toll thorough was good.28 This quid pro quo upheld a grant from the Crown and it also served the useful purpose of negativing the effect of the rule in prescription, that the people had a right to travel on highway free of charge. In several cases some of the judges doubted whether they could inquire into the original consideration of the toll thorough; inasmuch as the toll has been claimed from time immemorial, the court would be forced to presume it had a legal origin. $^{30}$

Whether or not the court was precluded from inquiring into the original status of a toll thorough may be a proper question for academic discussion, but it is of no practical importance. Every toll thorough could be supported on some form of consideration or public benefit. Among the various duties which have been held sufficient to support the toll are: the repairing of a bridge $;^{31}$ the paving of a street or causeway $;^{32}$ reparation of a sea bank $;^{33}$ the building of a wharf $;^{34}$ the maintenance of city walls for defensive purposes. ${ }^{35}$ In towns a toll for passing through was supported in one of several ways. If the route was made shorter this fact would support the toll for there would be a public benefit; and in addition the liability of repair was on the part of the lord. ${ }^{36}$ In the old town the whole area originally

\footnotetext{
${ }^{2}$ Heddy v. Welhouse, supra, note 27 ; Freeman v. Walgham, 2 Wilson, $296(1766)$.

20 Fitzherbert's Natura Brevium, 227 notes (p. 57\%, 8th ed.), citing Y. B. I4 Edw. III, Bar. 275 (I340) ; Y. B. 5 Hen. VII, Io (I490).

${ }^{20}$ Smith v. Shepherd, Croke Eliz. 710 (1600) s. c. Moore, 574; James v. Johnson, I Mod. Rep. 231 (1677).

"Supra, note I6.

"Supra, notes II and 20.

${ }^{23}$ The King v. Corporation of Boston, W. Jones Rep. I62 (1628).

"Supra, note 15. In Yarmouth v. Eaton, 3 Bwn. 1402 (1742), Lord Mansfield said, "the making of a port is itself a consideration, it may never require repairs; therefore I do not know that it is necessary to show repairs."

${ }^{*}$ Supra, note II.

* Warrington v. Morely, Combes Rep. 295, 297 (1694).
} 
belonged to the lord of the manor and as it was originally his soil he could plead the toll as a toll traverse, and relieve himself of showing a quid pro quo. ${ }^{37}$ It has also been said that the mere fact that the lord of the manor had granted a way to the public was sufficient consideration from which a toll thorough could be presumed. ${ }^{38}$.

Passage, ${ }^{30}$ therefore, would come under the classification of a toll thorough, for a ferry is a public highway ${ }^{40}$ and he who pays toll can demand transportation. The old abridgements and dictionaries classified the ferry as a privilege which could demand a toll thorough. Yet it appears to have grown up at the time when a toll thorough could not be claimed by either prescription or grant, for as early as $1444, \mathrm{Mr}$. Chief Justice Newton ${ }^{\mathbf{1 1}}$ speaks of an "ancient ferry". It is not unlikely that the ferry grew up as a private crossing and was gradually dedicated to the public. In the early law the rule was that the owner of a ferry had to own on both sides of the stream. ${ }^{42}$ This indicates that the traveller would have to cross the ferryman's land in order to reach the ferry. As the ferryman was the riparian owner on both sides of the stream, the road by ferry was only a continuation of his private road across the freehold and hence any toll that he would collect would be a toll traverse, for it has always been the law that a toll traverse was chargeable for passing over a private bridge or ferry..$^{43}$ And as it was a toll traverse, the owner, if he could show a reasonable toll from time immemorial, was protected in his ancient ferry. (r695)

" Prideaux v. Warne, 2 Lev. 96 (1673) ; Crispe v. Belwood, 3 Lev. 424

* Lord Pelham v. Pickersgill, I T. R. 660 (I787).

" It is also called ferriage by Kelham in his Norman-French Dictionary" (1799), page ro3.

"2 Danes Abridg. 683 (Mass. 1823).

${ }^{4}$ Y. B. 22 Hen. VI, pl. 14 b.

"Savile's Rep. II, pl. 29 (1581), and the reason was that the ferry franchise is in respect to the landing place and not in respect to the water, for if the owner did not own on both sides of the water he could not land. This harsh rule has been overthrown, Peter v. Kenda1, 6 B. \& C. 703 (Eng. 1827), where it was held that the owner did not have to have a property in the soil, only a right to land, such as on a highway. $C f$. Chambers v. Furry, I Yeates, 167 (Pa. 1792).

¿Heshord v. Wills, supra, note 22. 
After all it makes little difference whether the ferry toll grew up as a toll traverse or as a toll thorough. It is certain that since I444, when Mr. Justice Newton said the main reason for protecting an ancient ferry from infringement was that the owner was bound to keep it always in repair for the people or be severely fined, it has been considered as a toll thorough. The quid pro quo for the privilege was the public benefit that was derived from having at all times a suitable form of transportation across streams and rivers. The toll had to be reasonable; hence the courts were never impressed with the idea that the people would be oppressed by such a monopoly. ${ }^{44}$

Sir Matthew Hale in commenting on the King's rights in waters said that he has a "right of franchise or privilege, that no man may set up a common ferry for all passengers, without a prescription time out of mind, or a charter from the King. He may make a ferry for his own use or the use of his family, but not for the common use of all the King's subjects passing that way; because it doth in consequence tend to a common charge, and is become a thing of public interest and use, and every man for his passage pays a toll, which is a common charge. . . ."45 And still earlier, Sheppard in his 1 bridgement in speaking of tolls, wrote "that they were originally by King's grant, but now are claimed and may be had by prescription." It is interesting to note that in all the older cases dealing with ancient ferries the franchise was based not upon a grant, but upon prescription; a charter was never cited as the basis of the right. The declaration or pleas always stated that the owner of the ferry and his predecessors in title had been possessed of this privilege time out of mind. ${ }^{40}$

If, as counsel said in Churchman v. Tunstal,"7 "a ferry is a franchise, and a flower of the Crown which a private man :annot

4 What was a reasonable toll appears to have been a question for the court to decide. Coke, Second Inst. 222 ; Gard v. Callard, 6 M. \& S. 69 (Eng. 1817).

« Hargrave's Law Tracts, 6.

- For cases involving grants of ancient ferries from the Crown, see Pim v. Carrell, infra, note 99; Cowes Case, infra, note 99; General Estates Company $v$. Beaver, infra, note 63 .

${ }^{47}$ Hardres Rep. 162, 163 (1659). 
set up without a license", 48 it is hard to understand how prescription could perfect title in the user. However, the cases cited by counsel do not bear him out. In one of the cases Chief Justice Newton speaks of an ancient ferry in such a way as to lead one to believe he meant a ferry by prescription. But nevertheless it is old law that "a man can't prescribe in things which touch the Crown"," and "a prescription does not run against the King where he has a right". ${ }^{50}$ Yet along with these rules it was always the law that a toll could be gained by prescription. ${ }^{51}$ There are two theories which may explain this apparent contradiction.

If the true origin of the ferry was from the law of toll traverse, then the operation being upon the private land of the individual, the King could not complain. It would be a business where the King would have no special rights. And so when the idea of ferries had grown up to be fully recognized, and they were held to be in public service, the only way the court could protect the owner was to hold that by immemorial use he had obtained a franchise.

Then, again, it was possible for the King to have granted this franchise, for there is no doubt but that ferries were necessary and useful in the development of commerce and the country. As was said by Mr. Chief Justice Gascoigne:"52 "The King can charge the people of the realm without special assent of the commons on a thing that is a benefit to the people." By the application of the rule of immemorial use the court in order to protect the ferryman was compelled to presume the possible grant from the King. The obligation of the ferryman at all times to keep the ferry in proper condition for use was sufficient consideration to outweigh the rule that a toll thorough was against common right and an oppression to the people. If a toll could lie in prescription, ${ }^{53}$ there seems to be no reason why a

"Citing Y. B. II Hen. VI, 23 (1433); 22 Hen. VI, I4 (I444).

"Viner's Abridg., "Prescription", citing Brooke Lect's, Stat. Lim. 39.

${ }^{\circ}$ Ibid., citing $3^{8}$ Ass. 22 (1364).

${ }^{31}$ Coke Litt. II 4 b.

"3.13 Hen. IV, 14b (1412).

"Bracton (Lib. II, Chap. 24, s. 3), "But in other things, where proof is necessary, time runs against the King himself, as against others." And then he discusses inter alia the prescriptive right to take toll. 
ferry which was only one form of charging toll could not be gained by the same method. It is noticeable that all the tolls were to a certain extent necessary for the safety and development of the people. Murage kept up the walls for defense; pontage, passage and pavage made travel possible.

On this side of the Atlantic the courts are not in accord on the question of prescriptive rights in a ferry. Some of the States follow the English rule and hold that after a continued use the presumption may be drawn that the franchise had a legal origin. ${ }^{54}$ Others repudiate this method of gaining a ferry franchise and hold with Mr. Chief Justice Gibson, of the Supreme Court of Pennsylvania, that:55 "The right of navigation, transverse or otherwise, being enjoyed in common is susceptible of exclusive appropriation only by grant from the public to whom it belongs; and we have, consequently, no such a thing as prescriptive right or prescriptive grant of exclusive navigation from length of time. The doctrine of mullum tempus alone would prevent a title drawn from a source so like the statute of limitations, from being set up against the commonwealth or her grantee." erroneous quotation from the English cases and text-books to the effect that a franchise could be gained only by grant from

Milton v. Haden, 32 Ala. 30 (1855), in a suit by lessor of an ancient ferry against lessee for rents, held that after thirty years of continuous use, when the right of franchise is collaterally drawn in question, a presumption will be indulged in that the grant had legal origin. But there is dicta in Tuscaloosa County v. Foster, I32 Ala. 392 (IgOI), to the effect that a franchise for a ferry cannot be gained by prescription. Williams v. Turner, 7 Ga. 348 (I849); Hudspeth v. Hall, III Ga. 510 (I900), but will not presume an exclusive grant, Shorter v. Smith, 9 Ga. 517. Barrington v. Meuse Ferry Co., $69 \mathrm{~N}$. Car. 165 (1873), forty years or less will raise a presumption of a grant from the State. Dicta in McGowan v. Stark, I N. \& McC. 387, 9 Am. Dec. 712 (S. Car. 1818); City of Laredon v. Martin, 52 Tex. 548 (1880).

is Bird v. Smith, 8 Watts, 436 ( $\mathrm{Pa}$. 1839). However, the foundation of what is nearly as effective, is the power which the owners of the shores have to contro! the subservient and indispensable right of embarking and landing. The existence of such a power over even the termini of public roads is established in Chambers v. Furry, I Yeates, 167 (Pa. 1792); Cooper v. Smith, 9 S. \& R. 27 ( $\mathrm{Pa} .1822)$; Chess v. Manawn, 3 Watts, 219 (Pa. 1834).

st Accord: Murray v. Menefee, 20 Ark. 561 (1859); Trustees of Schools v. Tatman, I3 Iil. 27 (185I); Scott v. Wilson, II S. W. Rep. 303 (Ky. I889), but see Davis v. Connley, 46 S. W. Rep. 679 (Ky. I8g8); Sullivan v. Board of Supervisors, 58 Miss. 790 ( $188 \mathrm{r}$ ), overruling McFadden v. Board of Supervisors, 57 Miss. 618 (1880). 
the Crown. ${ }^{57}$ And some courts failed to appreciate that what was meant by franchise was only that the riparian owner had not, as an incident to the ownership of the land, the right to erect a public ferry and charge a toll.58 The term "franchise" did not exclude the possibility of gaining the right by prescription, for other franchises besides tolls could be gained by prescription. ${ }^{59}$

The idea of the benefit and recompense to the people at large which is derived from the ferry distinguishes the case from that where a subject and his ancestors have been squatters on the King's land for centuries. It is admitted that although one can dwell on the Crown's land forever-and-a-day, nevertheless he can be ejected, for in such a case the statute does not run against the Crown. But it seems that if one can establish an ancient ferry by prescription, it would be valid even as against the Crown. No direct case has been found, although there are several which approach this decision. In Year Book, 23 Hen. VI, I4b (1444), Mr. Chief Justice Newton said, in the course of an argument, that if one had an ancient ferry and another built another ferry so near to the ancient ferry that the profits were impaired, the ferryman had an action on the case because he was obligated to keep it in repair for the people or he would be severely amerced and brought before the Justices in Eyre. The second ferry the Chief Justice had in mind surely must have been a ferry by grant of patent, for there were only two possible ways to obtain a ferry franchise, by grant or prescription. It could not have been by prescription, for immemorial use could not have been proved. If the owner of the second ferry was not protected by his grant from the Crown, it would seem that in such a case the Crown could not have ousted the owner of the ancient ferry by a quo warranto proceeding. The same idea is brought out in Keeble v. Hickeringall, ${ }^{80}$ where Mr. Chief Justice Holt said:

\footnotetext{
"Excellent examples of this can be found in Appeal of James $E$. Douglass, $118 \mathrm{~Pa} .65$ (1888); Greensboro Ferry Co. v. New Geneva Ferry Co., 34 Pa. C. C. Rep. 33 (I907).

- Williams v. Turner, infra, note 62.

"See Viner's Abridgement, "Franchises".

“Holts Rep. 20 (I702) s. c. 90 Eng. Rep. (Full Reprint) 908.
} 
"In some cases you could not set up a franchise, tho' you have Letters Patents for it; as if I have a Ferry, I will bring an action against you for setting up another, for that $I$ am obliged to keep up mine for the good of the Publick, which would be hard upon me if you got all the Profit."ox

In both cases emphasis is laid upon the obligation incurred by the owner of the ancient ferry as the basis of his protection, but it is evident that the public benefit is the real reason. If the owner of the ancient ferry is not allowed to have the monopoly he cannot keep up the ferry in a way useful to the public, and hence the public would suffer. Just at this point the case of a ferry gained by prescription and of the attempt to gain the Crown's land by adverse possession differs. In the later case there is no public benefit; all the benefit would come to the adverse possessor and hence he is not protected.

Although many of the ancient ferries have been in use from time immemorial, nevertheless there is no one stated period during which a ferry must have been in existence before the jury can presume a grant from the sovereign. The periods required vary from seven years ${ }^{62}$ to six hundred years. ${ }^{63}$ It is a question of fact for the jury to determine whether there was an ancient grant, ${ }^{64}$ and the courts will seek to aid in the presumption of a legal origin of a right to charge tolls. ${ }^{65}$ The law was very well stated in Trotter v. Harris, ${ }^{66}$ which involved an action on the

- The better mode of obtaining protection today would be by a bill in equity to restrain the operation of the second ferry. The case of Churchman v. Tunstal, Hardres Ex. Rep. I62 (1659), refusing a bill on the ground that monopoly was bad, and no precedent for the toll is bad law and it was reversed in 1662 , see Huzzy v. Field, 2 C. M. \& R. 432, 44I (Eng. 1835); Dysart v. Hammerton, infra, note 99 ; General Estates Co. v. Beaver, infra, note 63 .

" Williams y. Turner, 7 Ga. 348 ( 1849 ), on an analogy to the statute of limitations for hereditaments.

- General Estates Co. v. Beaver, IIr L. T. Rep. 957 (Eng. Feb. 1915), which contains a very interesting history of that ancient ferry.

" Chichester v. Lethbridge, Willes Rep. 7r (Eng. 1738) ; Mayor of Hull v. Horner, Cowp. Rep. 102 (Eng. I774).

${ }^{\infty}$ Richards v. Bennett, I B. \& C. 223 (Eng. 1823).

- Y. \& J. 285 (Eng. I828). Various years have been held to have sustained the presumption: 350 years use by a city to charge a wharf toll, Mayor of Hull v. Horner, supra, note 64 ; 70 years, Hudspeth v. Hall, supra, note 54; 40 years, or less, Barrington v. Meuse Ferry Co., supra, note $54 ; 30$ years, Milton v. Haden, supra, note 54 . 
case for the disturbance of a ferry. The plaintiff alleged that he was possessed of an ancient ferry and proved continuous possession for thirty-five years. Upon a verdict for the plaintiff it was held by Lord Chief Baron Alexander:

"I agree that the commencement of a ferry must be by royal grant or license from the Crown, and that the grant must be shown or such evidence of ancient use must be adduced, as will satisfy the jury that it originally had that commencement, although the grant may not be forthcoming. But I can see no difference between this and other ordinary cases of prescription."er

\section{Baron Hillock said:}

'The word 'ancient,' usually found in declarations upon this subject, does not impose upon the plaintiff the necessity of produeing the grant from the Crown, but is satisfied by proving that the ferry has existed for such a time, as will raise the presumption of its being originally founded on right. If it be shown that the ferry had existed for a length of time, and the possession of the plaintiff be proved, that is sufficient to maintain the action. . . . We find the plaintiff in the possession of the ferry, in the exercise of a right, which if it could not exist but by deed, must have been presumed to have been legally created."

Since the ferryman was obliged to have his ferry running at all times, it was necessary for the public not to hinder him in the performance of his obligation. As early as $158 \mathrm{I}$ Savile $^{68}$ recorded that a ferryman "is privileged from being impressed as a soldier or otherwise. And it was so said in the case of the Inhabitants of Ipswich and $\mathrm{Phm}$. Brown". This has been since recognized in Ex Parte Fox, ${ }^{69}$ where Mr. Justice Buller said

"7 "But after so long a possession ( 36 years) I would presume anything in favor of the plaintiff (party in possession claiming grant)," Willes, $J$, in Roger v. Brooks, I T. R. 43 n. (Eng. 1784). "Now I apprehend that where there has been a long continued possession in assertion of a right, it is a well settled principle of English law, that the right should be presumed to have had a legal origin, if such legal origin was possible, and that the courts will presume that those acts were done and those circumstances existed which were necessary to the creation of a valid title," Lord Herschell in Phillips v. Hallidy, 64 L. T. Rep. 745 (Eng. I89I). Hence that which was stated in Walter v. Gunner, I Haggard Com. Rep. 314 (Eng. 1798), to the effect that the possession must be ancient and go beyond memory, but not high-legal memory, cannot be taken as a rule of law in each case.

* Page Ir, pl. 29.

${ }_{5}$ T. R. 276 (Eng. 1793). 
that the only case of exemption from being impressed by the government which does not rest upon the statute is of a ferryman.

The public aid is also shown in the fact that the English courts always construed the ancient ferry franchise to be an exclusive monopoly. This is interesting in view of the well settled rule that all grants from the Crown are construed strongly against the grantee.

The basic reason for this ruling is found in the utilitarian policy that what is best for the greatest number is the law. In I444 Mr. Chief Justice Newton gave as the reason for this protection that the ferryman was compellable to have adequate service and keep the ferry in proper condition. If he was bound to do this, then the law must in turn protect him from competition which would likely be ruinous to him. ${ }^{70}$ The courts were never alarmed over such a monopoly because the toll could only be reasonable, and hence they had the complete supervision of them. ${ }^{71}$ It was better for all concerned that one person have an exclusive monopoly, than that there be competition which in the end may be disastrous. The remedy afforded the owner of the ancient ferry to protect himself from competition was at first by an action upon the case, ${ }^{72}$ but later a more complete remedy was afforded by a bill in equity. ${ }^{73}$ Then, too, the Crown could always act in such a case against the second ferryman by quo zuaranto. ${ }^{74}$ Of course all these actions would be futile if the second ferry had been erected after an ad quod damnum. This writ was issued out of chancery commanding the sheriff to find by a jury what damage would be caused to the Crown or any

70 $22 \mathrm{Hen}$. VI, I4b. The injury to the owner of the ancient ferry is not in the gain made by the new ferry, but in the decrease of the tolls of his ferry, therefore a free ferry would be just as objectionable. Long v. Beard, 3 Mur. 57 (N. C. 1819).

"Churchman v. Tunstal; infra, note 73. It is interesting to note that the toll was hardly ever specified in the grant when such grant existed. Halsbury's Laws of England, vol. I4, page 560 .

72 Blisset v. Hart, Willes Rep. 508 (Eng. 1744).

$-{ }^{73}$ Churchman v. Tunstal, Hard. 162; 2 Anst. 608 (Eng. I659, reversed in 1662) ; Cory v. Yarmouth \& Norwich R. Co., 3 Hare. 594; 67 W. R. 516 (Eng. 1844).

- : "Blisset v. Hart, supra, note 72. 
other to grant a new franchise for a ferry. ${ }^{75}$ If the verdict was that no damage would be done, then no action would lie as the matter would be res judicata.

In those American jurisdictions which recognize the doctrine of ancient ferries there is a division as to whether the grant will be presumed to be exclusive or not. In Shorter v. Smith ${ }^{76}$ it was ruled that there could be no presumption that an ancient ferry had an exclusive monopoly. The reason for the rule was the same as controlled the decision of the Charles River Bridge Case $;^{77}$ namely, that it is contrary to the political institutions of this country to infer that a franchise grant is exclusive. A contrary result was reached in other jurisdictions which strictly followed the English law. ${ }^{78}$

To the general rule that an ancient ferry has an exclusive monopoly there are several qualifications or exceptions. (I) The monopoly is only of a crossing by ferry and not a monopoly of all modes of transportation across the river. (2) The obligation perpetually to keep up and run the ferry in proper condition must be present. (3) The doctrine of "new traffic" must be recognized.

I. It seems strange that the courts would rule that an ancient ferry was protected from infringement by another ferry, and yet would not go the whole way and hold that it was protected from all competition. The reason for the rule of monopoly seems as applicable if the infringement be by bridge. But the law is otherwise, and the reason is that the courts would not allow the development of a community to be restricted by the fact that an ancient ferry had to be protected; if other modes of transportation were more beneficial to the country, the ancient ferry must give way. ${ }^{79}$ The rule may be stated to be that the owner of an ancient ferry has not an exclusive grant of trans-

${ }^{75}$ I Bouvier Law Dict. I32 (Rawle, 3d Revision, 1914). See also Paine v. Patrick, infra, note 80 .

"9 Ga. 517 ( 1851 ).

"II Peters, 419 (U. S. 1837).

${ }^{73}$ Long v. Beard, supra, note 70; Smith v. Harkins, 3 Ired. Eg. 613; (N. Car. 1845); Barrington v. Meuse Ferry Co., supra, note 54; Stark v. McGowen, supra, note 54 .

Dibden v. Skirrow, [1908] I Ch. 4 I (Eng.); I Brit. R. Cases, 332, opinion of Farrell, L. J. 
porting passengers and goods across the stream by any means whatever, but only a grant of an exclusive right to carry them across by a ferry. In Pain v. Patrick ${ }^{80}$ the plaintiff sued the owner of an ancient ferry for refusing to ferry him. The defence was that the defendant had erected a bridge across the stream in place of the ferry he had abandoned. It was ruled that the defence "is not good, because the erecting of a bridge is but a laying out of a way; it is a voluntary act, and no man by reason of his own act can be discharged of what he is to do, upon the interest he hath in the ferry". ${ }^{81}$

In commenting upon this decision, Lord Justice Mellish ${ }^{82}$ said: "It seems a clear decision that he [the ferryman] has not a grant of every mode of carrying goods and passengers across; for if he had he would surely be entitled, if not bound, to provide the best means of crossing." This certainly is the logical result of the case, for if the grant was to transport people across, it would make no difference to the court how the people were transported. The Lord Justice's explanation of the theory of the grant is quite clear; he said:

"The first grantee of the ferry is supposed to have represented to the Crown that it would be for the public advantage that a ferry should be established in the particular locality, and, then, in consideration of the grantee undertaking perpettually to keep up the ferry, the Crown has granted to him the exclusive right of ferrying within certain limits. There is nothing in the nature of this transaction which would lead me to believe that the Crown intended to guarantee or had power to guarantee, the grantee of the ferry against changes of circumstances and future discoveries of an entirely different method of transit by which ferrying might be superseded. The Crown professes to

${ }^{*} 3$ Mod. Rep. 289 (Eng. 1690). This distinction between right to ferry and other modes of crossing is not always kept in mind, see Williams v. Turner, supra, note 62.

and a person entitled under an act to build a bridge and a ferry cannot substitute a ferry for the bridge and leave the bridge unrepaired, Nichol v. Allen, I B. \& S. 916 (Eng. I862).

"Hopkins v. Great Northern R. Co., 2 Q. B. D. 224 (1877). Here was a suit by an owner of an ancient ferry for disturbance of an exclusive franchise. The defendant railway, under the authority of an act, constructed across the river, a half a mile above this ancient ferry, a railway bridge, and a foot-bridge which was to be used by persons going to the railway station and other places. The traffic on the ferry rapidly declined and the ferry was abandoned. Held: No recovery. 
protect the grantee against the competition of other persons who are in the same line of business and do the same things that he does; but he appears to run the risk of any change of circumstances, which may render ferrying at that place useless. . - . It seems to us by no means clear that a person building a bridge over a stream, even in the line of a ferry, would be liable to an action by the owner of the ferry. It is true that the opening of a new bridge might be as prejudicial, or indeed much more prejudicial, to the property of the owner of the ferry than the setting up of a rival ferry; but the one does, and the other does not, involve the direct doing of the very thing the exclusive right to do which has been granted to the owner of the ferry; and it seems to be extending the principle of liability for an indirect violation of the rights of the owner of the ferry to an unreasonable extent, to hold that it extends to make a person liable to an action, who has not ferried or carried passengers by boat at all."

Although this may be considered obiter, nevertheless it was followed and affirmed in Dibden v. Skirrow, ${ }^{84}$ and plainly shows that the courts are not going to allow the owners of ancient ferry rights to clog the wheels of progressive transportation. The only case upon which the Lord Justice had a doubt was where a

* The reasoning of Reg. v. Cambridge Rwy. Co., L. R. 6 Q. B. 422 (Eng. 1871), was overthrown by this case. In that case the railway was empowered to build a railway bridge and footbridge across a river some several hundred yards above an ancient ferry. It was empowered to receive toll from those using it, and the consequence was that the profits of the ferry were greatly impaired. Held: That the owner of the ferry was entitled to damages for infringement. Lord Blackburn said: "The prosecutor's right is to a ferry, or a franchise, by which he had the exclusive right of carrying passengers across the river." It is submitted that this definition is incorrect in the light of Paine v. Patrick, supra, note 80 . It is only an exclusive franchise to carry by ferry. "It is well established that if that right is interfered with, without the authority of an Act of Parliament, by something which carries passengers across so close to it as to disturb the right, an action would be for that disturbance. The cases, so far as I remember them, in which actions have lain for the interference with, or disturbance of, the right of ferry, have been where there has been a carrying across by boats. But I cannot bring my mind to doubt the principle that if a bridge were to be erected across a ferry, and people were to go across the bridge, and consequently the bridge would have the effect of disturbing the owner of the ferry in his right, he would be entitled to bring an action on the case, and to recover damages."

It is clear that the point of difference between Blackburn, $J$, and Mellish, $J$., is that the former interprets the old cases broadly as holding that the interference of any kind of competition is actionable, while the latter construes them strictly as holding only competition by ferrying is actionable.

" [1908] I Ch. 61 (Eng.). For a complete note on the application of the principle in the United States see an excellent note in I Brit. Ruling Cases, 34I; also I Lewis Eminent Domain, \$216 (3d ed.). 
bridge was built at the very landing place of the ancient ferry, so as to enable persons to travel from the highway on which one terminus of the ferry was situated. In such a case he thought that the ferryman might have relief. The whole tenor of this excerpt is similar to that which prevailed in the opinion of the United States Supreme Court in the Charles River Bridge Case. ${ }^{85}$

2. Every ferry is not an ancient ferry, notwithstanding the remark in Stark v. McGowen ${ }^{86}$ that "the distinction which was attempted to be made between ancient ferries, and those by express grant, is without foundation; for when a ferry is prescribed for, it is upon the ground that there was originally $a$ grant which is presumed to have been made after a continued use of many years". It may be that a ferry by express grant is equivalent to an ancient ferry, but not necessarily so, for it will depend upon the obligation imposed upon the holder of the ferry franchise. The obligation imposed upon the owner of an ancient ferry, which after all was the benefit to the public at large, is the basis of the rights of ancient ferries. The ancient ferry franchise is in derogation of common right, but "as compensation for that derogation of common right, there is this great advantage to the public, that they have at all times at hand, by reason of the ferry, the means of travelling on the King's highway, of which the ferry forms a part; for the owner of the ferry is under the obligation of always providing proper boats, with competent boatmen, and all other things necessary for the maintenance of the ferry in an efficient state and condition for the use of the public . ..${ }^{87}$

The distinction between a ferry under a legislative grant and an ancient ferry is nowhere better brought out than in Letton v. Godden. ${ }^{88}$ In this case the plaintiff, the owner of a certain ferry provided for by an Act of Parliament, brought a bill to restrain the defendant from interfering with his right to an

Supra, note 77.

* Supra, note 54 . In this particular case the owner of the ferry by legislative grant was under the same obligations as the owner of an ancient ferry.

${ }^{8 \pi}$ Letton v. Godden, supra, note 2.

- Ibid. 
exclusive ferry from certain termini. Vice Chancellor Kindersley refused the bill because the plaintiff did not stand upon the same footing as the owner of an ancient ferry. "The right conferred on the plaintiff by the act was very limited and restricted. The right only applied to ferrying on Sundays, and although it was possible to conceive such a thing as a Sunday ferry, giving the right to convey the inhabitants of a parish to their parish church, on the other side of the river, there is nothing of the kind here." And lastly, the plaintiff was under no obligation to provide either sufficient boats or boatmen and could abandon his right whenever he pleased to do so. Hence if he was not subject to the obligation he could have no protection from competition for his claim was against common right. ${ }^{89}$

It was not always certain whether the failure of the ancient ferryman to fulfill his obligation would deprive him of his right to be free from ferry competition. The early law appears to be very precise in holding the man to his obligation. Sir Edward Coke, in speaking of the toll murage, which was taken in consideration of the upkeep of the wall of the town for defensive purposes, said: "But if a wall be made which is not defensible, nor a safeguard of the people, then ought not this toll to be paid, for the end of the grant of prescription is not performed." this reasoning no man could claim the toll for ferrying if he did not fulfill his obligation. And if he could not claim the toll, then surely he could not possibly be permitted to deprive any one else of ferrying if he were not willing to fulfill the conditions which were solely responsible both for his right to collect toll and right to be free from competition.

However, in Blissett v. Hart ${ }^{91}$ this reasoning is not followed. Here the plaintiff, owner of an ancient ferry, brought an action upon the case for damage from competition by the new ferry. The defendant objected to the declaration because it did not "aver in the declaration that the plaintiff kept boats and

\footnotetext{
* For the importance which is attached to the obligation of ancient ferrymen, see Londonderry Bridge Comm. v. McKeever, 27 L. R. Ir. $4 \sigma_{4}$ (C. A. 1890); General Estates Co. v. Beaver, supra, note 63 , in the opinion of Reading, C. J., at page 961 .

${ }^{2}$ Coke's Second Institute, 222.

"Supra, note 72.
} 
ferrymen sufficient to carry goods and passengers over the river". The court overruled this objection but gave no reason in the opinion filed. From a footnote which is found at the end of the case in the report, it is evident that Lord Chief Justice Willes thought any such suggestion was out of place in a civil suit, but ought to be called to the attention of the Attorney General, who would proceed by indicment. All that is necessary to aver for such protection is that the plaintiff is in possession of an ancient ferry. The same result was reached in Peter v. Kendal, ${ }^{92}$ where there was a similar action and the defendant proved that until he had set up his boat the ferry had been badly served and the public sustained much inconvenience. But to this Mr. Justice Bayley, in upholding the verdict for the plaintiff, replied:

"It is then said that the neglect of the plaintiff has destroyed his right to the ferry. I am of the opinion that neglect does not, ipso facto, destroy the right to the franchise. The proceeding by quo warranto supposes the party in actual, though not legal possession, and therefore judgment of ouster is necessary to dispossess him. In the case of an abuse of a franchise by negligence, the Crown may repeal the grant by scire facias or quo warranto, and may vest it in some other person, if that is thought necessary. But mere negligence in the party in whom the ferry is vested does not destroy the right."

In equity the rule is the same, and the chancellor will not go into the collateral question of whether the ancient ferryman lived up to the obligations when he is seeking protection by injunction. Although Lord Hardwicke, in a comparatively early case, ${ }^{93}$ did refuse such an injunction "because the plaintiffs had not shown that they had kept up sufficient ferryboats", nevertheless this is not the law today as evidenced by the latest decisions. ${ }^{94}$ While such a ruling may be criticised on the ground that both at law and in equity it protects the dog in the manger, nevertheless there are proper judicial avenues open for the correction of any

"6 B. \& C. 703 (Eng. I827).

"Dean of Durham's Case, I Ves. Sr. Chan. Rep. 476 (Eng. I750).

* Dysart v. Hammerton, infra, note 95; General Estates Co. v. Beaver, supra, note 63 , at pages 964 and 968 . 
just complaints on the part of the people and it is better for all concerned not to have these separate and distinct issues confused in one case.

3. The doctrine of "new traffic" is the result of a clash of two legal principles in respect to ancient ferries. The one is that the ferry has a monopoly of crossing the river by boat, the other that the ferry is established for the convenience of the public. The great question always is, how far must the ferryman give way to the convenience of the public, for it is evident from the cases which protected the ancient ferryman that the ease of a few people cannot alone be considered public convenience.

In order better to understand the problem it will be helpful to separate the two classes of ferry franchises in respect to the monopoly. These two classes are: (A) from vill to vill; (B) from highway to highway, or, as more commonly called, from point to point.

A. The franchise of an ancient ferry from vill to vill was one of the greatest monopolies known to the law, and only a few such franchises were ever reported in the cases. ${ }^{95}$ It is, therefore, important to understand what a vill is, and in a footnote is appended an excellent quotation from a very recent English case which thoroughly explains the origin and use of the term. ${ }^{96}$

${ }^{95}$ Phillmore, L. J., in General Estates Co. v. Beaver, supra, note 63, at page 964, mentions Trippe v. Frank, supra, and Huzzey v. Field, supra. But there are others such as Pim v. Currell, 6 M. \& W. 234 (Eng. I840); Cory v. Yarmouth, etc., Rwy., 3 Hare, 593 (Eng. 1844); Matthews v. Peache, 5 E. \& B. 546 (Eng. 1855); Newton v. Cubitt, I2 C. B. N. S. 32 (Eng. I862); Cowes v. Packet Co., [1908] 2 K. B. 287; Dysart v. Hammerton, I10 L. T. 879 (Eng. I914).

" Phillmore, L. J., in General Estates Co. v. Beaver, supra, note 63, at page 964 , "The word [vill], at one time in much use in legal matters, has almost dropped out of use in our later jurisprudence. But from Co. Litt. II5b; Viner's Abridgement, title Vill, and, with reference to the choice of juries, under the title Trial, number $\mathrm{Za}$, and following; Pollock and Maitland's History of English Law, bk. ii, ch. 3, Elphinstone on Deeds, pp. I68 and 624; and the cases of Stark v. Fox (Cro. Jac. I20), Lawrence v. Johns (Cro. Jac. 274), Wilson v. Law ( $r$ Ld. Ra. 20), and Addison v. Otway (I Mod. 250, 258; 2 Mod. 233), sufficient light on the subject can be gathered.

"For the purpose of the decisions I think the conclusion which I am about to state, though by no means exhaustive, will suffice. Every borough corporate or city is a vill, or, as Pollock and Maitland say, a group of vills. It seems to me possible that in cities where there are ancient divisions into wards the ward may take the place of the vill. Outside municipal corporations the rest of the country was supposed to be divided into country vills, zillac campestres. A country vill was not always, but generally, coterminous 
From this historical discussion the learned Lord Justice concludes that a vill was: "A defined legal area, in respect of which a franchise could be granted without uncertainty $;^{97}$ and when the franchise of a ferry from vill to vill was granted, the vill might either be a corporate borough or a villa campestris; and it would seem to follow that, as the franchise is recognized in the law as a distinct franchise, so it gave the privilege and involved the cluty of providing as many suitable lines of ferry as might be required for communication between two vills."98 But a mere franchise to run from one town to another was not necessarily a vill to vill franchise. This is well brought ont by Mr. Justice Kennedy in Cowes Urban Council v. Southhampton Stcam Packet Company, ${ }^{99}$ where there was a grant of a franchise from the Crown for "all that ferry or right of passage across the River Medina between East Cowes and West Cowes on the Isle of Wight". The owner

with a manor, and was thought of as having a lord. It had a defined circumscription and was the smallest civic area known to the law. The parish had been originally regarded as an ecclesiastical area, and seems only to have gradually acquired recognition as a unit of locality for temporal purposes; possibly not till the Statutes of Elizabeth (43 Eliz., c. 2) made it a unit for poor law purposes. Wherever, therefore, any act had to be described as done at a particular place, or a recovery of lands had to be suffered, or the habitation of any person had to be described, the proper territorial description was 'of such a vill in such county'; and though gradually the parish superseded the vill as a more convenient territorial description the conservatism of the officers of the courts, as narrated in the case of Addison v. Otway (2 Mod. 233), for a long time led them to refuse to use the word 'parish'. But in time, for convenience' sake, it was presumed that the parish and vill were conterminous, unless the contrary was shown. The division was carried to America. In New England the counties are divided into 'towns'; in the Central States of the United States into 'townships', as the smallest civil areas. . (See Fairlee on Local Government. The American States Series, ch. 829.)"

${ }^{97}$ In Tripp v. Frank, 4 T. R. 666 (1792), the court would not support a claim of franchise that was uncertain. The reason is that if it were uncertain the court could not well enforce the obligations to provide sufficient boats and routes. A franchise which was not pleaded with certainty could not be enforced.

* The same idea of larger obligations upon the owner of a vill to vill franchise is expressed by Lord Chief Justice Reading in the same case at page 961 . It was one reason which made him reluctantly find for a vill to vill franchise.

" [1905] 2 K. B. 287 (Eng.). Other cases where a vill to vill franchise has been denied are: Pim v. Currell, 6 M. \& W. 234 (Eng. I840); Matthews v. Peache, 5 E. \& B. 546 (Eng. I855); Newton v. Cubitt, 12 C. B. N. S. 32 (Eng. I862); Dysart v. Hammerton, stipra, note 95 . The point was discussed but not decided in Corry v. Yarmouth \& Norwich Rwy. Co., 3 Hare. 593,602 (Eng. I844). 
of this franchise in a bill to restrain infringement argued that both East and West Cowes should be treated as vills. But the Justice refused so to hold on the ground that from the maps produced in evidence it was clear that these places were districts and not vills. And he went further and ruled "that the Crown could not make a valid grant of a monopoly of ferriage throughout such a district". 100 The usual way of declaring a ferry right in a suit for infringement is to declare in the alternative; that is, that the plaintiff is possessed of an ancient ferry from vill to vill, or is possessed of an ancient ferry from point $A$ to point $B$. The court then will determine, largely from usage, whether the franchise claimed is a vill to vill or only a point to point. ${ }^{101}$

As the legal protection from monopoly in this vill to vill class of ferry, extends to the limits of the vill, it is evident that there cannot be much chance for the justification of competition under the doctrine of "new traffic". This is well brought out in Huzzey v. Field ${ }^{102}$ and the recent case of General Estates Company v. Beaver. ${ }^{103}$ In the former the main highway from Haverford to Pembroke passed by. Mayland, thence over the waters to Pembroke Point, and then inland for two miles to Pembroke. The plaintiff had a vill to vill ferry from Mayland to Pembroke. The defendant ran a ferry from Mayland to Peter Dock, a half-mile down from Pembroke Point, but on a new road to Pembroke. One day the defendant ferried a person to Peter Dock who while he was afloat said he was going to Pembroke. The court regarded this as a new ferry from Mayland to Peter Dock and hence no infringement of the plaintiff's ferry, they having disregarded the passenger's statements after he was afloat. But the court went into the question very thoroughly and

${ }^{100}$ The basis of this dictum is found in the argument of Mr. Cresswell and the answer thereto by Baron Maule in Pim v. Currell, supra, note 99 , at pages 259 and 260 ; and in Newton v. Cubitt, supra, note 99, at page 58.

${ }^{101}$ For such forms of declaration and methods of determining whether the franchise is from vill to vill or not, see Pim v. Currell, supra, note 99; Newton v. Cubitt, supra, note 99; Matthews v. Peache, supra, note 99; Cowes v. Southampton, etc., Steam Packet Co., supra, note 95; Earl of Dysart v. Hammerton, supra, note 95 ; General Estates Co. v. Beaver, supra, note 63 .

${ }_{102} 2$ C. M. \& R. 432 (Eng. I835).

${ }^{102}$ Supra, note 63 . 
laid down some rules which will hereafter be referred to. The reason for the thorough discussion was "that it may not be supposed that the decision to which we find ourselves obliged to come, can in any manner affect the plaintiff's right to the cxclusiz' privilege of ferrying passengers who leave Mayland, with no other object than that of going to Pembroke". Here it is evident that although Peter Dock was a half mile from Pembroke Point, yet if the defendant had known that the passenger intended to go to Pembroke, it would have been an infringement. The distance made no difference, nor the opening of the new highway from Peter Dock to Pembroke.

In the latter case the plaintiff claimed a franchise from the vill of Great Yarmouth, in the County of Norfolk, across the Yare to the vill of Little Yarmouth and Gorleston, in the County of Suffolk. After much argument both in the King's Bench and Court of Appeals the judges decided that it was a vill to vill franchise, considering Little Yarmouth and Gorleston as one vill. The plaintiffs operated two ferries, "Upper Ferry" and "Lower Ferry", about sixteen hundred yards apart. The defendant's ferry was located between these two, about four hundred yards above the "Lower Ferry". The justification was that the towns had developed so rapidly since the new fishing industry had grown up that this ferry was serving a new traffic. As the offending ferry was situated within the limits of the vill and as the court had decided that the claim of the plaintiff to a vill to vill franchise was sustained by evidence and rules of presumption, they never considered the question of new traffic and change of circumstances. ${ }^{104}$ It was only when the justices were considering the

${ }^{204}$ Phillmore, L. J., disposed of this new traffic argument as being applicable to a vill to vill ferry, as follows: "Assuming that in certain cases the connection of new highways coming down to the water on either side by new lines of ferry may not be a disturbance of a point to point ferry, still if these new highways come from and to parts of the area of the vills which are the subject of the franchise, it follows from the nature of the franchise that the owner has the duty of exercising it so as to comply with any reasonable convenience of the public, and corresponding privilege of preventing others from taking his place." This is the correct view of a vill to vill franchise and it sets aright the false impression given by Willes J., in his dictum in Newton v. Cubitt, supra, note 99 , at page 58. He was under the impression that a vill to vill franchise could not prevail against new traffic within the vills. He lost sight of the fact that a vill to vill ferry does exist in respect 
alternative claim of the plaintiffs, that at least they had two point to point ferries, did they consider the doctrine of change of circumstances and new traffic.

The only conceivable form of change which could possibly prevail against a vill to vill franchise is that which is mentioned by Lord Justice Mellish in Hopkins v. Great Northern Railzcay; ${ }^{105}$ that is, a change in the mode of travel. In this case the diversion of traffic was caused by the railroad bridge, and also a footbridge which enable intending passengers to cross the river for nothing. Here the new traffic was not caused by a change in circumstances in the neighborhood, "but there was a general change of circumstances in the country at large which rendered this new highway [the railroad] necessary, not only or principally for the accommodation of the persons who formerly used the ferry, but for the accommodation of a much larger number of the public".

B. A point to point ferry runs from the termini of a highway, and has no set geographical lines of monopolistic protection as does the vill to vill franchise. The doctrine of limiting the range of these ferries grew from the old idea which is always prevalent; namely, that of the public obligations of the ferryman and public convenience. The law is said to have had its origin with Lord Kenyon in Tripp v. Frank. ${ }^{106}$ The plaintiff in this action on the case for infringement was possessed of an ancient vill to vill ferry from Hull across the Humber to Barton. The defendant, possessed of an ancient ferry from Hull to Barrow, carried several persons to Barrow, two miles below Barton. It was held that the plaintiff could not recover. Lord Kenyon admitted that if the passenger had wanted to go to Barton, the

to the land and has a monopoly of all the traffic in the vill. He said "The ferry is unconnected with the occupation of the land, and exists only in respect to the persons using the right of way". This is only true of a point to point ferry and is not true of a vill to vill ferry. Phillmore, L. J., brings it out very clear where he distinguishes these two classes of franchises: "If the owner of a point to point ferry can always stop any one from ferrying in his line, by parity of reason the owner of a vill to vill ferry should be able to restrain ferrying over his area."

ius Supra, note 82.

${ }^{106}$ Supra, note 97 . 
mere fact that the clefendant carried them above or below the landing of the plaintiff's ferry would have made no difference. It would have been, as he states it, "a fraud on the plaintiff"s right" for the plaintiff had an exclusive (vill to vill) franchise. But the person did not want to go to Barton, "and it is absurd to say that no person shall be permitted to go to any place on the Humber than that to which the plaintiff chooses to carry them".

The court in order to protect the rights of the public was compelled to find for the defendant. As the plaintiff could be compelled to carry passengers only from Hull to Barton, the public would have been forced to cross the ferry to Barton and then walk down two miles to Barrow. This was unreasonable, and as it "is now admitted that the ferryman cannot be compelled to carry passengers to any other place than Barton, then this right must commensurate with his duty".

The same idea is brought out in Huzzey v. Field, ${ }^{107}$ which has been discussed before. All that Lord Abinger wanted to impress was that a vill to vill franchise was an exclusive monopoly only between the vills and not between the vill on one side and all the towns on the other side surrounding the other vill, for he said:

"It does not follow from this doctrine [that a vill to vill franchise is exclusive], that, if there be a river passing by several towns or places, the existence of a franchise of a ferry over it, from a certain point on the one side to a certain point on the other, precludes the King's subjects from the use of the river as a public highway from or to all the towns or places on its banks, and obliges them, upon all occasions, to their own inconvenience, to pass from one terminus of the ferry to the other."

It has been thought advisable to discuss these two cases at the outset, for although they do involve the question of new traffic and are cited as authorities for the rule, nevertheless they are really cases defining the limits of the protection of a vill to vill franchise.

One of the hardest questions in the law is to determine the extent of protection that is to be afforded a point to point ferry.

${ }^{107}$ Supra, note 102. 
It is certain that the owner of a ferry from $A$ to $B$ could enjoin any one who set up a new ferry adjoining the termini; and in Churchman v. Tunstal, ${ }^{108}$ a ferry operating within three-quarters of a mile from an ancient ferry was enjoined. It is also certain that there is a limit to this legal protection, for one cannot have a monopoly of a whole shore. What this limit is the authorities do not define.

Fleta states that no new market could be set up within seven miles. This distance was based on a calculation of a person travelling twenty miles a day, and hence he allowed seven miles out and seven miles back, with time for marketing. ${ }^{109}$ This arbitrary limit being based on the above reason might be suited to the simple wants of a rude life, where the inhabitants are few, says Mr. Justice Miller, ${ }^{110}$ "but is unfitted for large towns, where daily wants are greatly multiplied. Under the latter circumstances, it seems that the area within which a new market would become actionable, would be diminished from a diameter of fourteen miles by the public needs; and on the same reasoning, the area of a monopoly of a ferry would depend on the need of the public for passage."

In every case to solve the territorial limit of actionable proximity two main considerations must be balanced. The first consideration is "the advantage of preserving an ancient ferry, with the duties and liabilities of its owner, its fixed moderate tolls, and the obligation to serve at all hours and in all weathers, and the reasonable rights of the owner to the franchise, including his right to share in the improvements in the neighborhood". The other consideration is "the reasonable convenience of the public, when new highways bring them down to the waters' edge with corresponding new highways on the other side, in which case they may fairly complain if they are compelled to make an unreasonable detour". ${ }^{111}$

soe Supra, note 47 .

${ }^{102}$ Lib. IV, ch. $28, \S 13$.

${ }^{110}$ Newton v. Cubitt, supra, note 99 , at page 60 .

${ }^{11}$ Quotations are from the opinion of Phillmore, L. J., in General Estates Co. v. Beaver, supra, note 63 , at page 968 . 
The basis of the doctrine of new traffic or change of circumstances is found in Newton v. Cubitt, ${ }^{112}$ the celebrated Isle of Dogs Case. For the sake of convenience two possible divisions can be made here; namely, (a) new traffic due to the change in the circumstances of the neighborhood; $(b)$ new traffic due to the change in the mode of travel.

(a) In the Isle of Dogs Case, the Ferry Society tried for the fourth time to establish their claim to an exclusive ferry from the Isle to Greenwich-and failed. ${ }^{113}$ This island, about one square mile, is situated on the banks of the Thames, across from Greenwich. For a long time it was only a marsh, uninhabited except by persons working the ferry and a few cattlemen. In I8I2 there was only one road through it, Manor Way, which ran from Potters Ferry Stairs on the southerly end of the island in a northerly direction to the town of Poplar. The Ferry Stairs was the only means of access to a ferry between the Isle and Greenwich. About 1830 new factories, workshops and houses grew up on the island. The defendant in this case bought a large plot of ground on the east side of the island which abutted the Thames, called it Cubitt Town, and built houses and factories. Cubitt Town had about three thousand inhabitants. He also constructed a pier from which he started to run his ferry. This pier was by shore three-fourths of a mile, by road about seventenths of a mile, away from the plaintiff's ferry. There was no road connecting Cubitt Town with Manor Way except that which the defendant dedicated. The distance from Poplar to Cubitt Town was one and a half miles.

The plaintiff declared that the defendant operated a ferry near to the plaintiff's for the reason of diverting traffic. At the trial it was proved that the defendant had acted bona fide and had erected the ferry for the convenience of the inhabitants of Cubitt Town. But it was also proved that the defendant not only carried the inhabitants of Cubitt Town, but also other persons

12 Supra, note 99 .

212 The three other cases are: Giles v. Groves, 12 Q. B. 721, 6 D. \& L. 146, I7 L. J. Q. B. 273 (Eng. 1848); Blackeler v. Gillett, 9 C. B. 26 (Eng. 1850); Matthews v. Peache, supra, note 99 . A history of these cases is given on pages 39 and 40 of the report of Newton v. Cubitt, supra, note 99. 
who would have otherwise travelled to Greenwich by the plaintiff's ferry. However, these people (with one or two exceptions) did not live at Poplar, but merely worked on the island nearer to the defendant's ferry than plaintiff's ferry.

In holding that the defendant was not guilty, Mr. Justice Willes laid the foundation of this famous rule. After noting that the defendant had acted bona fide, and that there was no known test to determine the actionable proximity of a new ferry, he said:

"It seems reasonable to infer, that, if the franchise of a ferry is established for the facility of passage, and if the monopoly is given to secure convenient accommodation, a change of circumstances creating new highways on land would carry with it a right to continue the line of those ways across a water highway; and it is obvious that the single landing-place which sufficed for an uninhabited marsh, would be utterly inadequate for several towns thronged with industrial mechanics. If one hundred of such laborers pass now to Greenwich where one traveller passed in I800, it seems oppressive to fix on such a large number of laborers the perpetually repeated loss of threequarters of a mile of walking, for the sake of the small fraction of the toll which is the profit on each passenger, and unreasonable so to increase that profit."

The noticeable thread which runs throughout this quotation is "public convenience". Never for a moment does the learned Justice once consider the corresponding right on the part of ferryman to benefit in the development of the island. It is a one-sided view of the question, and does not weigh the rights of one against the rights of the other. It may well be that the geographical situation made it impossible for him to hold otherwise, but at least he did not give much weight to that reason. His main theme was the public convenience which is plainly seen in the statement of his idea of the rule: "If the public convenience requires a new passage at such a distance from the old ferry as makes it to be a real convenience to the public, the proximity seems to us not actionable."

Not only did the justice refuse to consider the right of the plaintiffs' benefit in the reasonable growth of the community, but would not even protect him from the diversion of the former 
patrons from Poplar, for he held that all at Cubitts Pier, whether they come from Poplar or elsewhere had the right to use the Thames either to Greenwich or elsewhere at their free will by ferry or steamer.

The same idea of public convenience is brought out in Dixon v. Curwen. ${ }^{114}$ Here the defendants had leased an ancient ferry plying across Lake Windemere from $A$ to $B$, which was about a mile from Bowness, to the plaintiff, and agreed to allow no "opposition ferry" to land on the property. However, the defendants did grant to a ferry which ran up and down the lake the right to stop at $A$ and carry passengers to Bowness, and vice versa. The plaintiffs brought a bill to enforce the contract, contending that this was an "opposition ferry". The Master of the Rolls dismissed the bill because there was no legal interference with the plaintiffs' rights. The mere fact that the plaintiffs had a ferry from $\mathrm{A}$ to $\mathrm{B}$ did not oblige the people to cross from one terminus to the other, "on all occasions, to their own inconvenience". The case is poorly reported and the facts do not show whether there was a road from $B$ to Bowness, but if there was, then it is very doubtful whether the case is good law. It certainly does not agree with the well considered ruling of Huzzey v. Field. ${ }^{115}$

The next case was Cowes Urban Council v. Southampton Steam Packet Company, ${ }^{116}$ where the plaintiffs were lessees from the Crown of an ancient ferry on the Isle of Wight from a point in West Cowes across the Medina River to East Cowes. Since I90I the ferrying had been carried on by steam bridges, barges and rowboats. The defendants were owners of steamboats which ran from the mainland to West Cowes. Their ferry across the Medina was situated at West Cowes about one-half mile north of the ancient ferry, and at East Cowes about one-eighth mile to the north, and was used both by patrons in East Cowes who wished to make a through trip to the mainland and by persons who merely wished to cross from West to East Cowes and

114 [1877.] Weekly Notes, 4 (Eng.). The case is very short and the Master of the Rolls did not go into a thorough discussion of the matter.

${ }^{315}$ Supra, note 102.

211 Supra, note 99 . 
vice versa. The defendants' landing at West Cowes was nearer the seaside and the fashionable part of the town; and a railway which ran to points on the Isle of Wight had a terminus near it and had made suitable transfer arrangements. At East Cowes their landing was near Osbourne, which had lately grown up, and the northern part of the town. Since 1902 the traffic between the towns had increased immensely, due to the fact that a pier was established near the defendants' West Cowes' landing, where excursionists from the mainland alighted. The plaintiffs' business during all this time had been progressive. Their ferry could accommodate all that used it and more if the passengers, to use Mr. Justice Kennedy's finding, "had disregarded their own convenience and had gone out of their way to follow the steam bridge route".

The plaintiffs did not seek to enjoin the defendants from ferrying those people of East Cowes who wished to make a through trip to the mainland, recognizing the ruling made by Lord Justice Mellish in Hopkins v. Great Northern Railway, ${ }^{117}$ but they did contend that the defendants were otherwise interfering with their ancient ferry. The court, however, thought that the traffic which the defendants were carrying was new traffic, and hence there could be no interference. Apart from the locating of the railway terminus near the defendants' ferry, and the establishment of the Royal Naval College, and the opening of Osbourne to the visitors, "there has grown up and now exists in West Cowes, to the west and north of the defendants' ferry, a number of residents who could not, without considerable inconvenience, lose the advantage of that ferry".

It is very evident that Mr. Justice Kennedy was led by the opinion of Mr. Justice Willes which he quoted at length. Hc, too, only considered the public convenience. The mere fact that people would have to walk a half mile to the plaintiffs' ferry was sufficient to justify a new line of carriage. He never considered that plaintiffs might have been compelled to establish another line where the defendants were now, and if they might have been

${ }^{117}$ Supra, note 82. 
compelled, they surely were entitled to protection. He thought that the traffic from all these sources was new traffic, for the reason-and this is the new theory advanced by him-"that the traffic on the ancient ferry is at the same time not diminishing but an increasing and progressive traffic." The fact that the traffic of the ancient ferry has not diminished but grown can have nothing to do with the question of actionable interference and received the earnest denunciation of Lord Chief Justice Reading in a recent case. ${ }^{118}$

With the advent of the Earl of Dysart v. Hammerton, ${ }^{119}$ the doctrine of "public convenience" is greatly limited and the corresponding right of the ancient ferryman is considered. The plaintiff was possessed of an ancient ferry from Twickenham to Ham. A few years before the bill was brought, Parliament had empowered various public bodies to preserve the view from Richmond Hill, and accordingly Marble Hill Park, on the Twickenham side was purchased and improved. On the Ham side of the river the Earl had converted an old foot path into a public recreation ground where many visitors came on holidays. The defendant's ferry was situated near the recreation park and the plaintiff's was more than a quarter of a mile away. Any person who wanted to cross to Marble Hill Park would have had to go a quarter of a mile up the stream to the ancient ferry and when across would have had to come back a quarter of a mile. The majority of passengers carried by the defendant were pleasure seekers to whom the ferry was a real convenience, although other people were carried. The lower court following the above considered cases, refused the injunction on the ground of new traffic. This was reversed by the Court of Appeals. Lord CozenHardy, Master of the Rolls, placed a limitation upon public convenience when he ruled that "the mere fact that it would be convenient for persons living 500 yards away from the ancient ferry is not in itself sufficient". There must be more than a mere personal convenience to each person using the ferry. In fact there

11" General Estates Co. v. Beaver, supra, note 63, at page 963.

sss Supra, note 95 . 
must be a new traffic and the importance of this case is that it holds that public convenience alone cannot create this new traffic.

Lord Justice Phillmore, in his concurring opinion, points out the real fact which is to determine the right of new ferry lines. He quoted that part of Mr. Justice Willes' opinion which stated that the creation of new highways on land will give the right to create new ferry lines to connect them. He then remarked that in the case under consideration there was no such highway on the land created since the promenade dedicated by the Earl could not be considered such a highway. $\mathrm{He}$ also pointed out that in the Cowes Case, which was never acted upon by the Court of Appeal, there were new highways created on the land which distinguished it from the case at bar. ${ }^{120}$

This case then brings out in bold relief the fact that new highways must be created on land, which ought to be united by a ferry for the public convenience; and that public convenience in and of itself will not create new traffic.

The broad doctrine of public convenience received its death blow at the hands of Lord Chief Justice Reading in an opinion handed down in February of this year in General Estates Company v. Beaver, ${ }^{121}$ where he said:

"It may well be that it would be convenient to some members of the public to have another ferry a little higher up, or a little lower down. Every one would prefer to be ferried directly across the river without having to walk some distance along the bank to or from the ferry, but that convenience in itself is an insufficient reason for holding that the establishment by another of a ferry in the proximity of an ancient ferry is not an interference with the right of the owner."

\footnotetext{
${ }^{20}$ Buckeley, L. J., dissented, and at page 886 laid down a new test: "It is essential, I think, to discriminate between, first, traffic (including increased traffic due to altered circumstances), which, having regard to the approaches of the river theretofore existing, would naturally go to the plaintiff's ferry, and secondly, traffic which for want of better accommodation must go to the plaintiff's ferry, because there is not such a new communication, as, if that be the case, the public convenience properly demands. The ferry owner is entitled to the former, that is the traffic which would go, but not to the latter, that is the traffic which must go for want of better accommodations, to his ferry." The weakness of this test is the inability to distinguish between those who "would naturally go" and those who "must go". Where a new ferry is created it would be almost impossible to separate the two groups.
}

${ }^{223}$ Supra, note 63, at page 962. 
The Chief Justice then explained that the term "public convenience" as used by Mr. Justice Willes in the Isle of Dogs Case, could not possibly mean that it would merely be convenient to the people at the north end of the island and at Cubitt's Town to have a ferry across the Thames in proximity to the ancient ferry. But it must be understood in the light of the facts and that public convenience can only arise when new highways of traffic have been established on the land. Lord Justice Phillmore explained the expression in the same manner. He also pointed out that in that case, none of the traffic was connected with the old Manor Way leading from the Stairs to Poplar, but it was fresh traffic from a new town, requiring a totally different line of ferrying. It is not contended that this interpretation of the facts is not better than that given by Mr. Justice Willes himself, but it is believed that the idea of new lines of traffic on the land was not the prominent thought in his mind, but rather the convenience of the public. He argued that as the public through the Crown had created the ferry for their convenience, they could easily enough create a new one.

The other important point of this case is the emphasis placed upon the right of the ferryman to insist upon his privilege to share in the growth of the community. In speaking of this, the Lord Chief Justice said that the ancient ferryman has a right to say to those who want to be ferried across, "you must cross by my ancient ferry; here am I, possessed of this right, and I provide a suitable boat and charge a reasonable toll and am liable to be indicted if I fail to perform my obligations to the public in return for my exclusive right of ferry". If the ferryman did not have this right, an ancient ferry from point to point would confer no legal right except at the exact line of crossing.

Some of the facts have already been recited, but there are others which have an important bearing on this subject. Up until 1867 the important industry of these towns, the herring fishery, was carried on by sailing trawlers and drifters; now it is carried on by steam drifters. Instead of being smoked, the herring are now pickled, and consequently there has been an increase in this industry. About twenty thousand people come to these towns during fishing season. There had also been an in- 
crease in shipbuilding and naval engineering work. New parts of the towns had been laid out with streets and houses on both sides of the banks. It was estimated that the workers who crossed in the defendant's ferry, if compelled to use the plaintiff's, would have an extra walk of at least three-fourths of a mile a day. Surely if the growth of the town and the public convenience were the sole guides, no person was more justified than the defendant in this case and so the court thought. But the ancient ferryman is also to be considered and he has the right to have his ferry grow with the community. Why should he be deprived of any part of it because the right has become more valuable due to the increase of population and extension of the works? "It is old traffic in the sense that it is old industry, which is being carried on by new and different methods. It is old traffic under altered circumstances and different conditions. In the ordinary and natural course of human affairs population will increase, new houses will be built, progress in methods and extension of industries will take place, and that is what has happened here." The court pointed out, that if the ferry accommodations were not such as they should be, the plaintiff can be compelled to improve the service. But he is the one to gain the increased business and no other.

It is true that the parts of the opinion of Lord Chief Justice Reading and Lord Justice Phillmore, which deal with the question of actionable proximity and limit the ruling of Mr. Chief Justice Willes in the Isle of Dogs Case and practically repudiate the Cowes Case, can be considered obiter, because they had already decided that it was a vill to vill franchise; nevertheless, one cannot read these well considered opinions without being impressed that what has been said is well grounded law.

Under the subhead of new traffic caused by a change of circumstances in the neighborhood, another point may be well discussed, and this may be termed a change in the character of the patrons. It was first noticed in the Cowes Case, where one of the reasons given for new traffic was that a great many of the defendant's patrons were excursionists who came to West Cowes. While Mr. Justice Kennedy did not remark about it, this class 
of traffic was totally different from what the ancient ferryman had been used to handling, for his trade was composed of citizens of East and West Cowes. This distinction was given an impetus by Lord Justice Phillmore in Dysart v. Hammerton. ${ }^{122}$ Here most of the defendants' patronage was from the pleasure seekers and excursionists. Referring to this, he said:

"As to the ferriage of the first class, I have been in considerable doubt. Ferries in their inception were for people on business and not on pleasure bent. The pleasure-seekers, the exercise-taker, was an exceptional case. It is possible to regard the river [the Thames] in this respect as if it was an artificial piece of water, like the Serpentine, bisecting a pleasure ground. If the defendants had proved . . . that they had ferried persons resorting to the park and not otherwise,-or rather, if it had not been proved against them that they did more, I should have been in doubt whether any injunction ought to have been granted."

But this can no longer be urged as a justification, for in the recent case this argument was used in behalf of the defendant. The justice replied that he had gone very far in the former case for special reasons and upon further consideration his doubt had been greatly diminished and now thought that the unqualified opinion of the Master of the Rolls was correct. If the expression "class of traffic" means that a new type of persons are traveling for a new purpose, there is no reason why this should justify a new service. Indeed if this were not so, it would be denying the ancient ferryman the right to share in the increase of the neighborhood. It makes no difference what takes the passenger across the ferry, work or play, the main point is that he crosses and the ancient ferryman is entitled to his toll.

A rule may then be stated to be: In a point to point ferry the actionable proximity is a question of fact to be decided by all the circumstances, but that no new service can be justified except on the ground that new highways of travel have been created in the neighborhood which are separate and distinct from the ones leading to the ancient ferry, and that it will be for the convenience of the public to have these new highways connected.

${ }^{12}$ Supra, note 95 , at page 888. 
(b) The new traffic caused by a change in the mode of travel can very easily create a change in the neighborhood. In Hopkins v. Great Northern Railway Company, ${ }^{123}$ where the doctrine originated, the change in mode of travel caused a change of circumstances in the neighborhood. The company built in close proximity to the plaintiffs' ancient ferry a railroad which crossed the river. The court had ruled that as the monopoly at the best only protected the ferry from competition by other ferries, the railroad bridges could not be considered an infringement. But Lord Justice Mellish went further than this. After remarking that the railroad had created a new highway on land and created a new mode of travel, he ruled that even had the railway bridge never been built, "but the railway company had established a neze ferry for the purpose of conveying goods and passengers from their railway on the one side of the river to the railway on the other side, it would not have been actionable, for the railway would have been a new highway on land, which a change of circumstances had rendered necessary, and it would be reasonable that the new highway should be allowed to be continued over the water highway". True it is that there is a mere obiter, yet is it not sound? Does it not follow the rule of Newton v. Cubitt ${ }^{124}$ as restricted by Dysart v. Hammerton ${ }^{125}$. and General Estates Company v. Beaver? ${ }^{126}$ The only possible limitation that could be placed upon this ruling is that the passengers are to be limited to the railway travelers. ${ }^{127}$

${ }^{22}$ Supra, note 82, at page 233.

${ }^{224}$ Supra, note 95.

${ }^{123}$ Supra, note 95 .

12. Supra, note 63 .

${ }^{27 x}$ The ferry in this ruling differs from the free bridge which was erected along with the railroad bridge to accommodate the railway travelers. The difference is that the bridge was no infringement at all, and although some did cross who did not intend to travel by rail, yet the company was not responsible for this. On the other hand, the ferry would be prima facie an infringement and is only excused because it carries the traveler by rail who would otherwise not cross. In such case the company would have to discriminate between the passenger by ferry and refuse to carry those who did not intend to make 2 through journey by rail. 
The principle of new traffic caused by a through journey was first enunciated in Hopkins v. Great Northern Railway, ${ }^{128}$ and then recognized by the ancient ferryman's counsel in the Cowes Case, ${ }^{120}$ when he made an exception to that traffic between East and West Cowes which he described as through traffic-that is, persons who are carried across the Medina as a part of a continuous transit between East Cowes and the mainland, where that part of the transit from the mainland to West Cowes has been or is to be performed by the defendants' steamers. It is evident that such traffic is entirely new to the ancient ferry, it was created solely by the other ferryman and he is the one to benefit from it.

$$
\text { Douglass D. Storey. }
$$

Laze School, University of Pennsylvania.

12 Supra, note 82.

Supra, note 99. 